\title{
Scientific Approach in Improving Science Learning Activities of Madrasah Ibtidaiyah Students
}

\author{
Syamsidar HS ${ }^{1}$, Samsinar $\mathbf{S}^{2}$ \\ ${ }^{12}$ Institut Agama Islam Negeri Bone, Indonesia
}

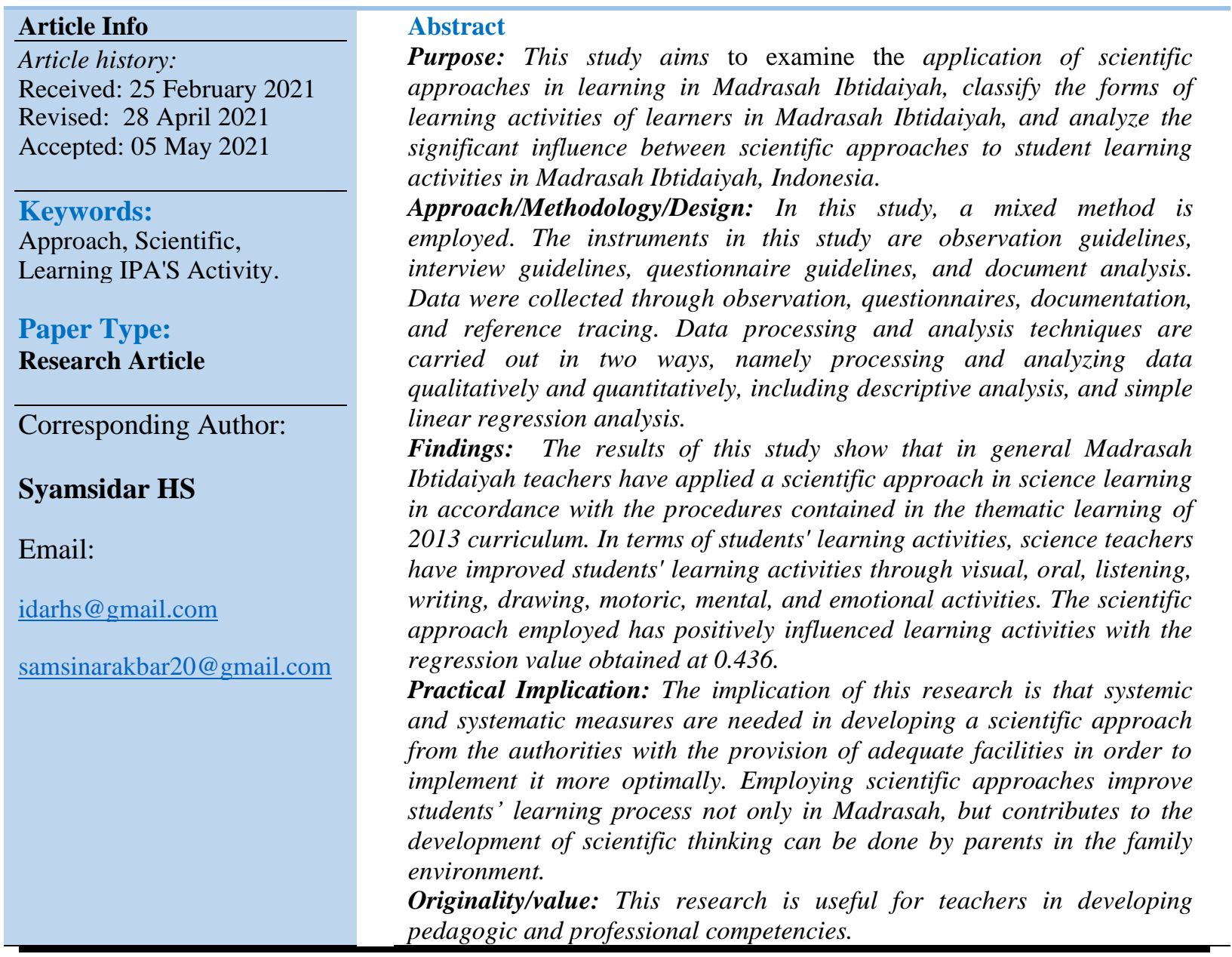

\section{Introduction}

Curriculum is a handle used in the process of organizing school education in the form of references, plans and norms to achieve certain educational goals (McKernan, 2007). Curriculum 2013 was developed to realize national education, namely to develop the potential of learners to become human beings who believe and fear God Almighty, noble, healthy, knowledgeable, capable, creative, independent, and become democratic and responsible citizens (Republic of Indonesia, 2006). The development of learners should be done gradually in accordance with the psychological development of learners. 
Education at the elementary school level or Madrasah Ibtidaiyah should focus on affective development or attitudes and behaviours (Demina et al., 2019). Teachers are tasked with guiding students to know and develop their potential so that they become human beings in accordance with the mandate of the law above.

The implementation of curriculum 2013 marked a paradigm shift in the learning process in Indonesia. Learning is student-centered and also directed to encourage learners to find out various sources of observation (Wangid, 2014). Learning is directed to formulate problems, not just solve problems, learning is directed to train analytical thinking skills (decision making) instead of mechanistic thinking (routine), and learning emphasizes the importance of cooperation and collaboration in solving problems (Daryanto, 2014).

The types of learning activities of learners can be grouped into eight parts, namely viewing, listening, writing, drawing, speaking, moving, mental and emotional activities (Diedrich et al., 2010). This grouping of learning activities shows that the activities in Madrasah are quite complex and varied. If these activities can be created in Madrasah surely Madrasahs will be more dynamic and a center for maximum learning activities.

Madrasah Ibtidaiyah as one of the formal educational institutions under the auspices of the Ministry of Religious Affairs has used the 2013 Curriculum and teachers have implemented the scientific approach recommended in the curriculum, especially in Grade 1 and Grade IV. This study is focused on analyzing the output of employing approached in 2013 Curriculum on Grade IV students. The steps of scientific approaches are supposed to nurture a high-level thinking ability and train learners to communicate ideas. Hence, the focus in this research study is on Grade IV and natural sciences (SCIENCE) learning. Science subjects are considered difficult for learners, so teachers have to apply student-centered approaches, such as scientific approaches, to balance between soft skills and hard skills of learners that include affective, cognitive and psychomotor.

\section{Literature Review}

The learning approach sets a general direction or clear trajectory for learning that includes more precise or detailed components. The learning approach is a series of correlative assumptions related to the nature of learning. The learning approach is also interpreted as a point of view for teachers towards the learning process, including teacher-centered approaches and student-centered approaches (Yaumi, 2013). One of the approaches centered on learners is the scientific approach. This approach is applied to the 2013 Curriculum to achieve core competencies, basic competencies, and impact on the achievement of graduate competency standards covering three areas of learning, namely attitudes and good behaviors based on religious values formulated in core competencies 1 (KI 1) and based on socio-cultural values expressed in core competencies 2 (KI 2). It also includes skills to use methods and tools as procedural knowledge (Sundayana, 2014).

In the 2013 curriculum, the suggested approach is a research-based learning approach and emphasizes the modern dimension of pedagogy in learning i.e. using scientific or scientific approaches. Scientific approach to the 2013 curriculum, the learning process takes place by 
combining inductive and deductive approach, which only utilizes existing knowledge and theories, learners accept and make it part of new knowledge (Kosasih, 2016). So this scientific approach is an approach that collaborates between inductive and deductive approaches.

Scientific approach is also interpreted as an approach that does not depend on teachers (Hosnan, 2014). So this approach emphasizes scientific procedures and the information is obtained from a variety of learning sources. observation activities for the formulation of hypotheses or collecting data (Sani, 2015). From the explanation above, the learning with scientific approach has the following characteristics: (1) Student-centered, the learning experience is obtained through activities relevant to the knowledge and skills that need to be mastered and needed by learners (Sani, 2015). (2) Involve the skills of the design process in constructing concepts, laws, or principles. (3) Engage potential cognitive processes in stimulating intellectual development, particularly students' high-level thinking skills. (4) Can develop the character of learners (Daryanto., Karim, 2017). (5) The purpose of learning is formulated simply and clearly, and the presentation system attracts students (Nurdin \& Adriantoni, 2016). Thus, the essence of the scientific approach is an approach that in its learning activities prioritizes creativity and discovery of learners with the following characteristics: (1) The learning material is understood by logic standards in accordance with the level of maturity. (2) The learning interaction takes place openly and objectively. (3) Students are encouraged to always think analytically and critically, precisely in understanding, identifying, solving problems, and applying materials in learning (Kosasih, 2016).

Thus, the characteristics of scientific approach seen from the process both material, interaction, and results achieved from learners will provide better learning outcomes and make learners able to think analytically and critically, so that if they get problems in students both learning problems and problems outside of learning will be solved scientifically. The purpose of learning with a scientific approach is based on the advantages of that approach. Some of the learning objectives with a scientific approach are: (1) to improve intellect skills, especially the high level of thinking skills of learners. (2) To shape the ability of learners in solving a problem systematically. (3) The creation of learning conditions so that students feel that learning is a necessity. (4) Obtained high learning outcomes. (5) To train learners in communicating ideas, especially in writing scientific articles. (6) To develop the character of students (Daryanto., Karim, 2017). There are several steps in applying scientific approaches in the 2013 curriculum, namely: 


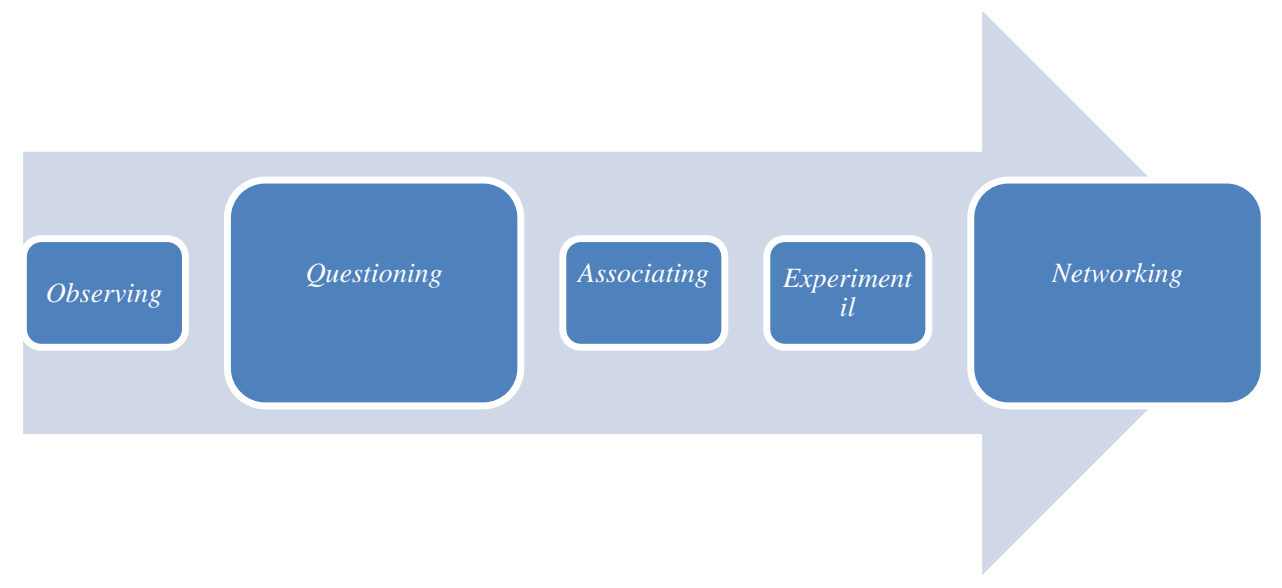

Figure 1.1 Scientific Approach Measures in Learning

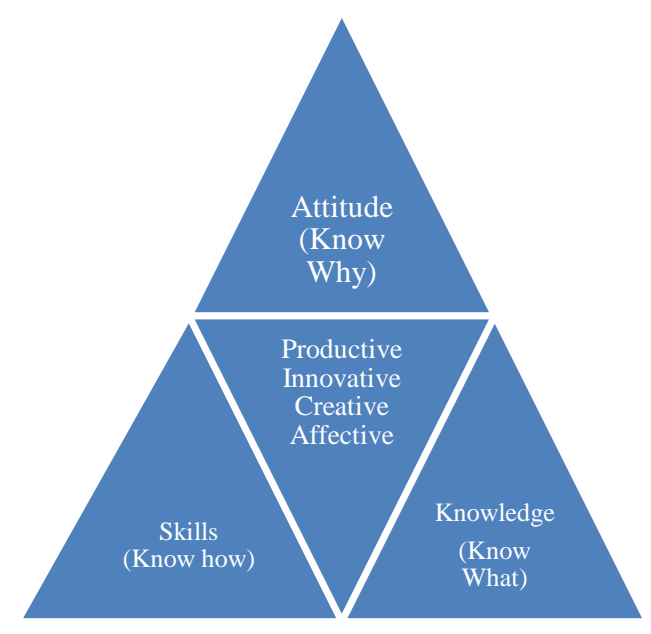

Figure 1.2 Three Domains Touched in the Scientific Approach

The result of this scientific approach is the improvement and balance between the ability to be a good human being and a human being who has the skills and knowledge to live decently from learners which include attitudes, knowledge and skills (Nurdin \& Adriantoni, 2016). Scientific methods generally involve observation, formulation of hypotheses, experiments, and verification activities through theory, models and results or data obtained (Sani, 2015). For more details, the process can be seen as follows: 


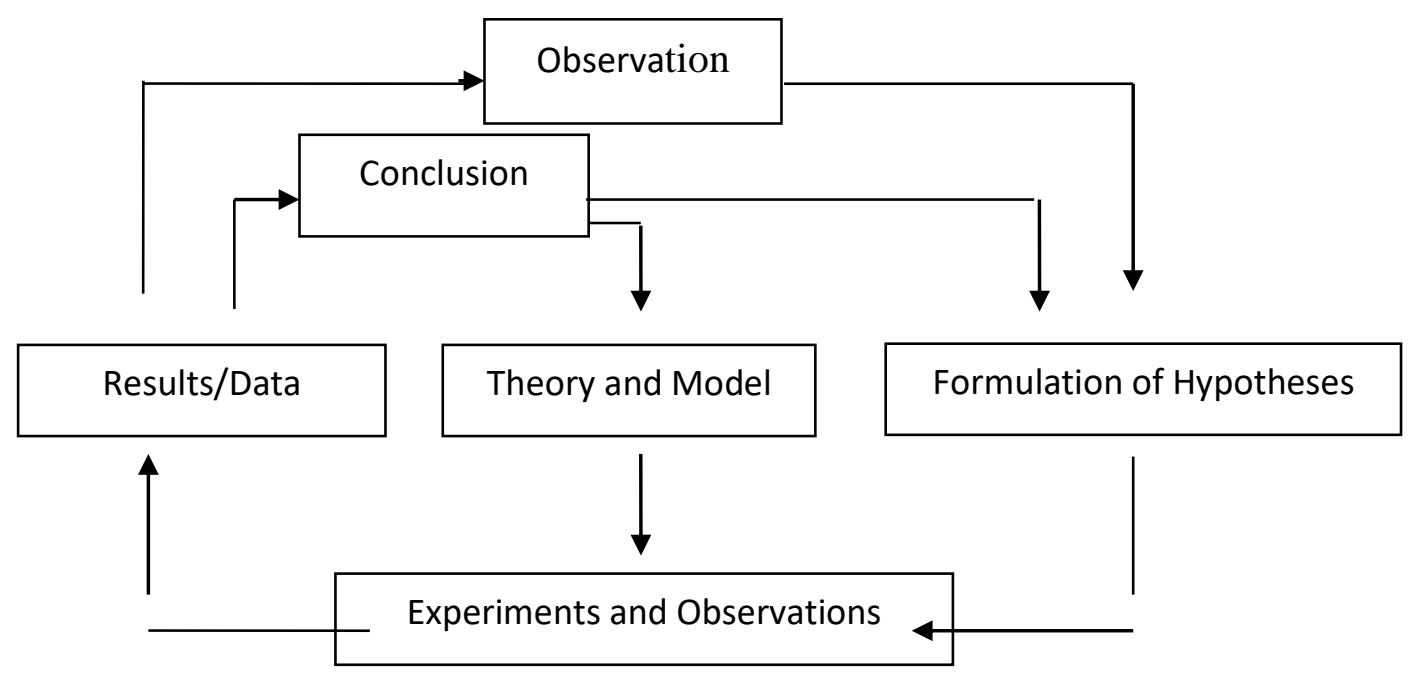

Figure 1.3 Components of Scientific Activity

This scientific activity is carried out in learning activities either in physical and psychic activities or in collaboration with both. The purpose of this activity is to encourage the occurrence of student activities that can be directly observed by teachers. The direct observable activity is physical activity, as it is easier to measure. Nevertheless, psychic activity is sometimes manifested in physical activity (Kadir \& Asrohah, 2014). Learning activity is the whole activity of learners in the learning process ranging from physical activities to psychic activities. Learning required activities are very important and recommended for the development of project methods, problem-solving, which is the motto that he popularized is learning by doing (Sardiman, 2001).

According to cognitive theory, the learning process teaches learners able to identify, formulate problems, search and find facts, analyze, interpret and draw conclusions (Rusman, 2015). Because the learner has an active spirit, the teacher must bring about that activity in learning with a scientific approach. In addition to the theory of cognitive learning, humanistic learning theory suggests that the main goal of teachers is to help learners to develop themselves (Mudlofir \& Rusydiyah, 2016).

Table 1: Linkage between steps or Stages in Learning with Scientific Approach with Learning Activities and Their Meaning

\begin{tabular}{|l|l|l|}
\hline \multicolumn{1}{|c|}{$\begin{array}{c}\text { Step Activities } \\
\text { Learning }\end{array}$} & \multicolumn{1}{c|}{ Learning Activities } & \multicolumn{1}{c|}{ Competencies Developed } \\
\hline Observing & $\begin{array}{l}\text { Reading, listening, listening, } \\
\text { viewing (without or with tools) }\end{array}$ & $\begin{array}{l}\text { Train seriousness, thoroughness, } \\
\text { search for information }\end{array}$ \\
\hline Questioning & $\begin{array}{l}\text { Ask questions about information } \\
\text { that is not understood from what } \\
\text { is observed or questions (from } \\
\text { factual questions to hypothetical } \\
\text { questions) }\end{array}$ & $\begin{array}{l}\text { Develop creativity, curiosity, the } \\
\text { ability to formulate questions to } \\
\text { form critical thinking that is } \\
\text { necessary to live intelligently and } \\
\text { learn throughout life }\end{array}$ \\
\hline
\end{tabular}




\begin{tabular}{|l|l|l|}
\hline $\begin{array}{l}\text { Collecting Information/ } \\
\text { Experiments }\end{array}$ & $\begin{array}{l}\text { Conduct experiments, read } \\
\text { sources other than textbooks, } \\
\text { observe objects/events/activities, } \\
\text { and interview with sources }\end{array}$ & $\begin{array}{l}\text { Develop a conscientious, honest, } \\
\text { polite attitude, respect the opinions } \\
\text { of others, communication skills, } \\
\text { apply the ability to gather } \\
\text { information through various ways } \\
\text { learned, develop learning habits and } \\
\text { learning throughout life }\end{array}$ \\
\hline $\begin{array}{l}\text { Processing Information } \\
\text { /Associating }\end{array}$ & $\begin{array}{l}\text { Processing information that has } \\
\text { been collected is both limited } \\
\text { from the results of collecting } \\
\text { activities / experiments and the } \\
\text { results of observing activities and } \\
\text { activities collecting information. }\end{array}$ & $\begin{array}{l}\text { Develop honest, conscientious, } \\
\text { disciplined, rule-abiding, hard } \\
\text { work, ability to apply inductive and } \\
\text { deductive thinking procedures and } \\
\text { abilities in concluding }\end{array}$ \\
\hline $\begin{array}{l}\text { Communicating and } \\
\text { Networking }\end{array}$ & $\begin{array}{l}\text { Convey observations, conclusions } \\
\text { based on the results of oral, } \\
\text { written, or other media analysis } \\
\text { through cooperation between } \\
\text { students and experts, teachers and } \\
\text { other sources }\end{array}$ & $\begin{array}{l}\text { Develop } \\
\text { conscientiousness, tolerance, } \\
\text { systematic thinking skills, express } \\
\text { opinions briefly and clearly, and } \\
\text { develop good and correct language } \\
\text { skills }\end{array}$ \\
\hline
\end{tabular}

\section{Methodology and Procedures}

This research is field research and the type of research is a mixed method. This combination method using concurrent embedded model or design is a research method that combines qualitative and quantitative research methods by mixing the two methods unbalanced (Sugiyono, 2011). In this research activity, $70 \%$ used qualitative methods and $30 \%$ used quantitative methods. In this method, use qualitative method merging model as primary method and quantitative method as secondary method. The research instruments used are interview guidelines, questionnaire guidelines, observation guidelines and documents.

The study also used populations and samples. The population in this study was all science teachers at Madrasah Ibtidaiyah in Watampone and all Grade IV students at Madrasah Ibtidaiyah in Watampone. The distribution of population in this study is as follows:

Table 2: State of IPA Teacher Population in Madrasah Ibtidaiyah Watampone

\begin{tabular}{|c|l|c|}
\hline No & Science Teacher at Madrasah Ibtidaiyah Watampone & Population \\
\hline 1 & Madrasah Ibtidaiyah Al- Ma'rif Saliwang Benteng & 2 People \\
2 & Madrasah Ibtidaiyah Negeri 7 Bone-Macanang & 2 People \\
3 & Madrasah Ibtidaiyah Al- Amin Cabalu & 1 Person \\
4 & Madrasah Ibtidaiyah Syamsu Rasyidi Majang & 1 Person \\
5 & Madrasah Ibtidaiyah Darul Hikmah & 2 People \\
6 & Madrasah Ibtidaiyah Baitul Hamdi & 1 Person \\
7 & Madrasah Ibtidaiyah Tomoponreng & 1 Person \\
\hline \multicolumn{2}{c}{ Total } & 10 People \\
\hline
\end{tabular}

Data Source: MAdrasah Ibtidaiyah Watampone,2017.

The population for teachers in this study was 10 people $<100$ people then the population sample was saturated. Furthermore, the population for learners in this study can be seen as follows: 
Table 3: State of Student Population Toweld IV in Madrasah Ibtidaiyah Watampone

\begin{tabular}{|c|c|c|}
\hline No & Grade IV Students at MAdrasah Ibtidaiyah Watampone & Population \\
\hline $\begin{array}{l}1 \\
2 \\
3 \\
4 \\
5 \\
6 \\
7\end{array}$ & $\begin{array}{l}\text { Madrasah Ibtidaiyah Al- Ma'rif Saliwandng Benteng } \\
\text { Madrasah Ibtidaiyah Negeri } 7 \text { Bone-Macanang } \\
\text { Madrasah Ibtidaiyah Al- Amin Cabalu } \\
\text { Madrasah Ibtidaiyah Syamsu Rasyidi Majang } \\
\text { Madrasah Ibtidaiyah Darul Hikmah } \\
\text { Madrasah Ibtidaiyah Baitul Hamdi } \\
\text { Madrasah Ibtidaiyah Tomoponreng }\end{array}$ & $\begin{array}{l}36 \text { People } \\
37 \text { People } \\
21 \text { People } \\
18 \text { People } \\
77 \text { People } \\
8 \text { People } \\
8 \text { People }\end{array}$ \\
\hline & Total & 205 People \\
\hline
\end{tabular}

Data Source: MAdrasah Ibtidaiyah Watampone, 2017.

Based on the table above, the population of students in Class IV is 205 people. Sampling-based on the above population is done by means or techniques of non-probability sampling or a sampling technique that does not provide equal opportunities or opportunities for each element or member of the population to be selected into a sample. Therefore, this research is mixed methods so qualitative research used purposive sampling techniques that are data source sampling techniques with certain considerations.

\section{Table 4. Purposive Sample Condition of Grade IV Students at Madrasah Ibtidaiyah} Watampone

\begin{tabular}{|c|l|c|}
\hline No & \multicolumn{1}{|c|}{ Students at MAdrasah Ibtidaiyah Watampone } & Number of Samples \\
\hline 1 & Madrasah Ibtidaiyah Al- Ma'rif Saliwandng Benteng & 6 People \\
2 & Madrasah Ibtidaiyah Negeri 7 Bone-Macanang & 6 People \\
3 & Madrasah Ibtidaiyah Al- Amin Cabalu & 3 People \\
4 & Madrasah Ibtidaiyah Syamsu Rasyidi Majang & 3 People \\
5 & Madrasah Ibtidaiyah Darul Hikmah & 6 People \\
6 & Madrasah Ibtidaiyah Baitul Hamdi & 3 People \\
7 & Madrasah Ibtidaiyah Tomoponreng & 3 People \\
\hline & Total & 30 People \\
\hline
\end{tabular}

Data Source: Determination of Samples of Students at Madrasah Ibtidaiyah Watampone, 2017.

The technique of collecting data by distributing questionnaires is a list of statements about certain topics to subjects both individually and in groups to obtain certain information (Hajar, 1996).

The documentation technique is one of the qualitative data collection methods by viewing or analyzing documents made by the subject himself or others about the subject (Herdiansyah, 2010). This is to obtain teacher data about learning tools in science subjects including syllabus and teaching materials as well as lesson plans (lesson plans). Document analysis will be carried out by recording documents that the teacher has and does not have, studying the lesson plan and the completeness of its components both learning objectives, indicators, methods that are in accordance with the scientific approach, media, and 
evaluation. Data processing in this study was carried out in two ways, namely processing data qualitatively and processing data quantitatively. With a Likert scale, the variables to be measured are translated into variable indicators, then these indicators are used as a starting point for compiling instrument items which can be in the form of statements or questions (Sugiyono, 2011). For scoring according to the following Likert Scale:

Table 5: Score Setting for Variables for the Application of Scientific Approaches and Student Learning Activities in Madrasah Ibtidaiyah Watampone

\begin{tabular}{|c|c|c|c|c|c|}
\hline \multicolumn{2}{|c|}{ Answer Options } & $\begin{array}{c}\text { Always } \\
\text { (SL) }\end{array}$ & $\begin{array}{c}\text { Often } \\
\text { (SR) }\end{array}$ & $\begin{array}{c}\text { Sometime } \\
\text { S (KK) }\end{array}$ & $\begin{array}{c}\text { Never } \\
\text { (TP) }\end{array}$ \\
\hline $\begin{array}{c}\text { Statement/ } \\
\text { Questions }\end{array}$ & Positive & 4 & 3 & 2 & 1 \\
\cline { 2 - 6 } & Negative & 1 & 2 & 3 & 4 \\
\hline
\end{tabular}

The technique of analyzing data is adapted to the questions or statements and hypotheses in this study. Statements or questions and hypotheses asked in this study in accordance with qualitative and quantitative analysis, namely: (1) Qualitative analysis is inductive i.e. an analysis based on the data obtained, further developed into hypotheses. (2) Descriptive Analysis of Quantity. Quantitative descriptive analysis is performed on the raw data obtained to facilitate understanding and know the level of each variable. Analyze data with frequency distribution using the formula:

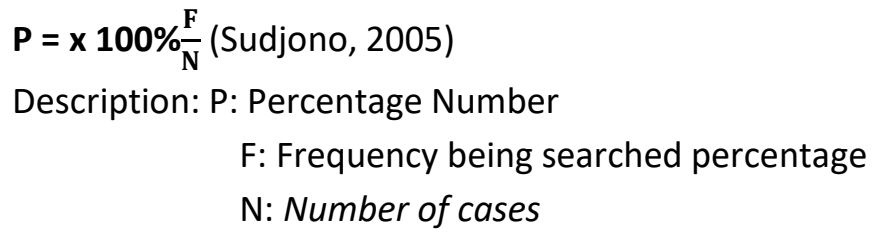

Inferential analysis was carried out by using the instrument test. There are two test instruments used in this study, namely the validity test and the reliability test. With the test criteria if $\mathrm{r}$ count is greater $(>) \mathrm{r}$ table then the measuring instrument is declared valid, and vice versa if $r$ count is smaller $(<) r$ table then the measuring instrument is invalid (Arikunto, 2006). Data analysis was performed with the help of the SPSS program. In addition to the validity test, the reliability test was also used in this study. Reliable means or reliability. SPSS provides facilities to measure reliability with the Cronbach Alpha $(\alpha)$ statistical test. A construct or variable is said to be reliable if it gives a Cronbach Alpha value greater (>) 0.70. (Ghozali, 2011). Hypothesis tests can be performed with simple linear regression analysis, $\mathrm{t}-$ test, or partial significance test and determination test. The tests are:

\section{Simple Linear Regression Analysis}

Simple linear regression analysis is used for one free variable $(\mathrm{X})$ or independent against one non-free or dependent variable (YRumus simple linear regression to know there is a significant influence on the increase of learning activities of learners in Madrasah Ibtidaiyah Watampone, namely: 


$$
\begin{aligned}
& \text { Y-a+b.X } \\
& \text { Description: } \begin{array}{l}
Y=\text { Bound Variable } \\
X=\text { Free variable } \\
\text { a and } b=\text { Constants }
\end{array}
\end{aligned}
$$

Make a decision on whether Ha or Ho is accepted and accepts or rejects Ho. Decision making in t-test with SPSS if:

Probability > significance level (5\% or 0.05$)$, then Ho accepted and Ha rejected, while probability < level of significance (5\% or 0.05 ), then Ho was rejected and $\mathrm{Ha}$ accepted. Furthermore, based on the results of the t-test obtained with the help of SPSS will produce a table of correlation coefficients (correlation coefficient). To be able to give an interpretation of the correlation coefficient found large or small, it can be guided by the provisions listed in the following table:

Table 6: Interpretation of Correlation Coefficient of $t$ Test Results

\begin{tabular}{|c|c|}
\hline Coefficient Interval & Relationship Level \\
\hline $0,00-0,199$ & Very low \\
\hline $0,20-0,399$ & Low \\
\hline $0,40-0,500$ & Moderate \\
\hline $0,60-0,799$ & Strong \\
\hline $0,80-1,000$ & Very Strong \\
\hline
\end{tabular}

Partial Determination Coefficient

This partial determination coefficient is an analysis used to determine the percentage contribution or contribution of the influence of independent or independent variables on the dependent or dependent variable. This partial determination coefficient is used to determine the contribution or contribution of the effectiveness of the scientific approach to increasing student learning activities at Madrasah Ibtidaiyah in Watampone.

\section{Results and Discussion}

\section{Application of Scientific Approach to Science Learning in Madrasah Ibtidaiyah}

Scientific approach has been applied by science teachers at Madrasah Ibtidaiyah in Watampone, but not yet maximum. The Head of MI at Watampone stated that MI provides opportunities for students to gain new experiences and teachers as facilitators or mediators (Rafi, 2017). He also indicated that MI provides training on the application of $\mathrm{K}-13$ in thematic learning especially SCIENCE including scientific approach and good assessment of attitude, cognitive or knowledge and psychomotor. This training is usually conducted at the beginning of each semester and also MGMP (Subject Teacher Deliberation) or KKG (Teacher Working Group) activities in Madrasah Ibtidaiyah in Bone District (Harnida, 2017). The steps taken by science teachers in applying scientific approach or scientific approach to Madrasah Ibtidaiyah in Watampone are: 


\section{Observing}

Science Teacher presents images, uses media in presenting materials, associates the initial knowledge of learners, raises the enthusiasm of learners by associating the learning experience of learners in real life. The percentage result of the activity is as follows:

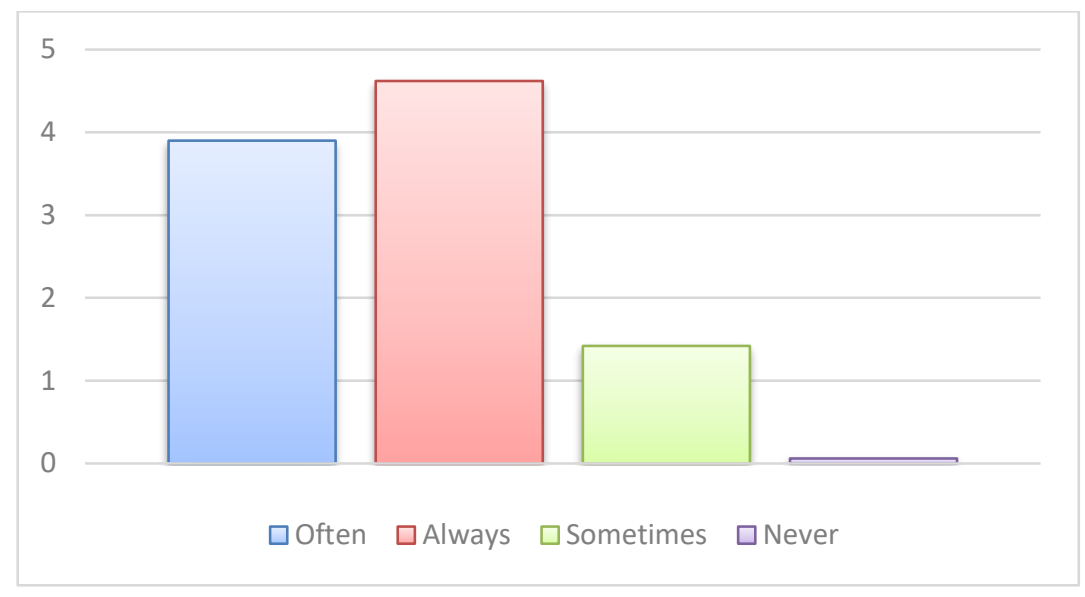

Figure 1.1 IPA Me Teacher conducts Observing and Science Learning

Based on the table above, then in general IPA teachers always do observing activities as one of the steps in scientific approach. It is seen in the figure above that the frequency of science teachers stated often 3.4 (34\%), always $5.2(52 \%)$, sometimes $1.4(14 \%)$, and never $0(0 \%)$ not do this in science learning activities. Observing activities reinforce learning. Reinforcement can be in the form of rewards and punishments. Reward in the form of compliments and gifts (Harniati, 2017).

\section{Questioning}

In doing questioning, science teachers ask questions about what is not understood from what is observed and ask questions both factually and hypothetically. The percentage result of the activity is as follows:

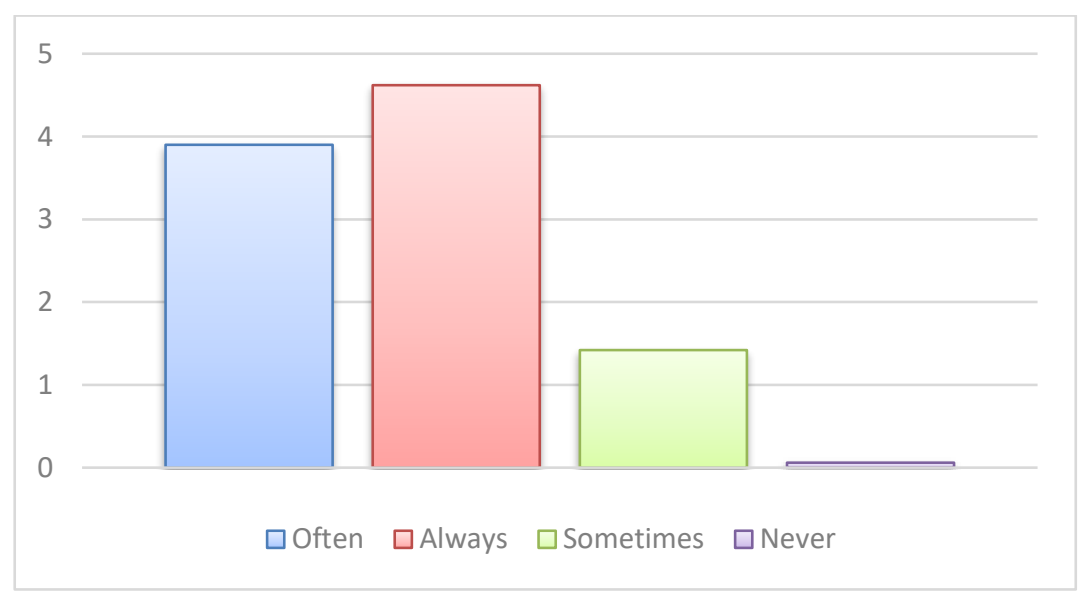

Figure 1.2 Science Teacher Medo Questioning and Science Learning 
Based on the figure above, then in general IPA teachers always do questioning activities as one of the steps in the scientific approach. It is seen in the figure above that the frequency of science teachers declaring often 3.4 (34\%), always 5.5 (55\%), sometimes 1 (10\%), and never $0(0 \%)$ do not do this in science learning activities.

\section{Experimenting}

In conducting experiments, science teachers use other sources outside of textbooks, observe objects, events, activities, and conduct interviews. The percentage result of the activity is as follows:

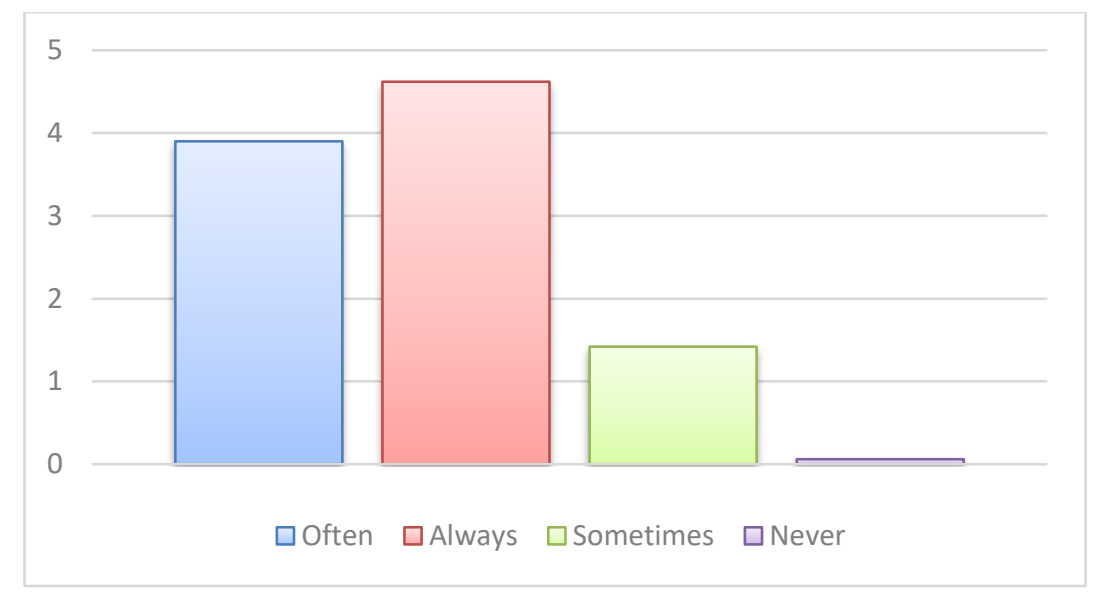

Figure 1.3 IPA Me Teacher experiments with science learning

Based on the figure above that the frequency of science teachers expressed often $3.4(34 \%)$, often5.5 (55\%), sometimes $1(10 \%)$, and never $0(0 \%)$ do not do this nature science learning activities. At the time of the experiment, the teacher asked us to prepare the tools to be used for the experiment, usually; he divided the group, so as not to burden the learners. As at the time of the material about the encroachment of sound, we were asked to prepare pieces of pipes, plastic bags, rubber bands, mattress threads, and matchsticks. This tool is prepared to experiment with simple phone making. Similarly, the encroachment of sound through the air or gas objects, the teacher prepares a flute. The teacher asked one of us to ring the flute. The sound of flutes creeping through the air so that it is heard by other students (Rezki, 2017).

\section{Associating}

The fourth step taken by science teachers in their learning is associating. At this stage, science teachers process information from the results of experiments, observe and collect information that adds breadth and depth, as well as solutions from various sources both different and conflicting (Tenriawaru, 2017). In addition to the interview above, the results of the questionnaire or percentage of this activity, are seen based on the following table: 


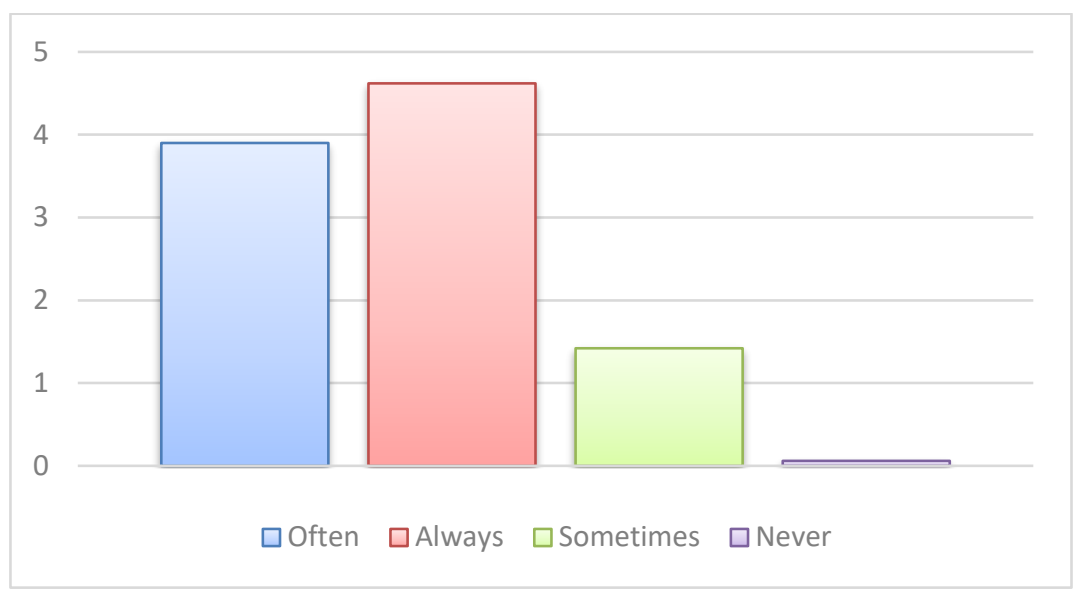

Figure 1.4 IPA Me Teachers do Associating in Science Learning

Based on the table above, then in general science teachers always do associating activities as one of the steps in scientific approach. It is seen in the figure above that the frequency of science teachers declaring often $2(20 \%)$, always6 (60\%), sometimes $2(20 \%)$, and never 0 $(0 \%)$ not do this in science learning activities.

\section{Networking}

The last step of the scientific approach is networking. At this stage ipa teachers deliver the results of observations, concluding the results of analysis either based on oral, written, or other media.

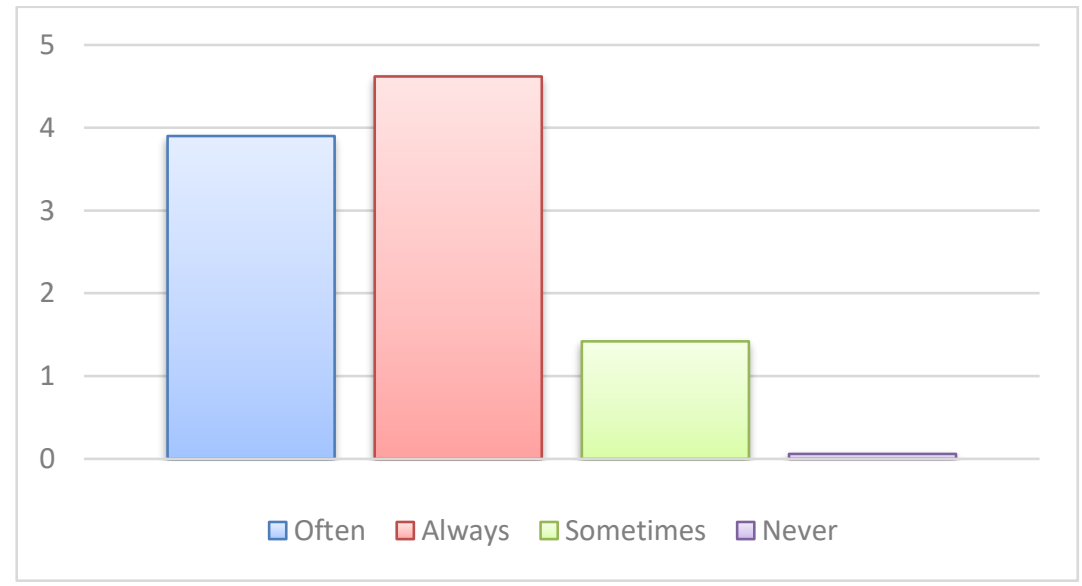

Figure 1.5 Science Teachers Perform Networking in Science Learning

Based on the table above, the frequency of science teachers networking more often 5.2 (52\%), always $4.4(44 \%)$, sometimes $0.4(4 \%)$, and never $0(0 \%)$ do not do this in IPA learning activities. Way cross read between learners. The results that have been obtained are written on a piece of paper and after completion, the paper is scrambled and given to other learners to read ( Singer \& Alexander, 2017). Presenting the results of the experiment of one of the group members, the other group corrected what had been delivered and questioned what was less clear than what was conveyed (Siyati, 2017). Forms of networking activities are offered, such as e-emantulan and sound absorption. Students are asked to look for images and identify or classify objects reflected with objects that absorb sound. Objects that can 
bounce and make sounds such as gongs, drums, and objects that absorb sounds such as cloth, cotton, foam, cork, paper, and so on.

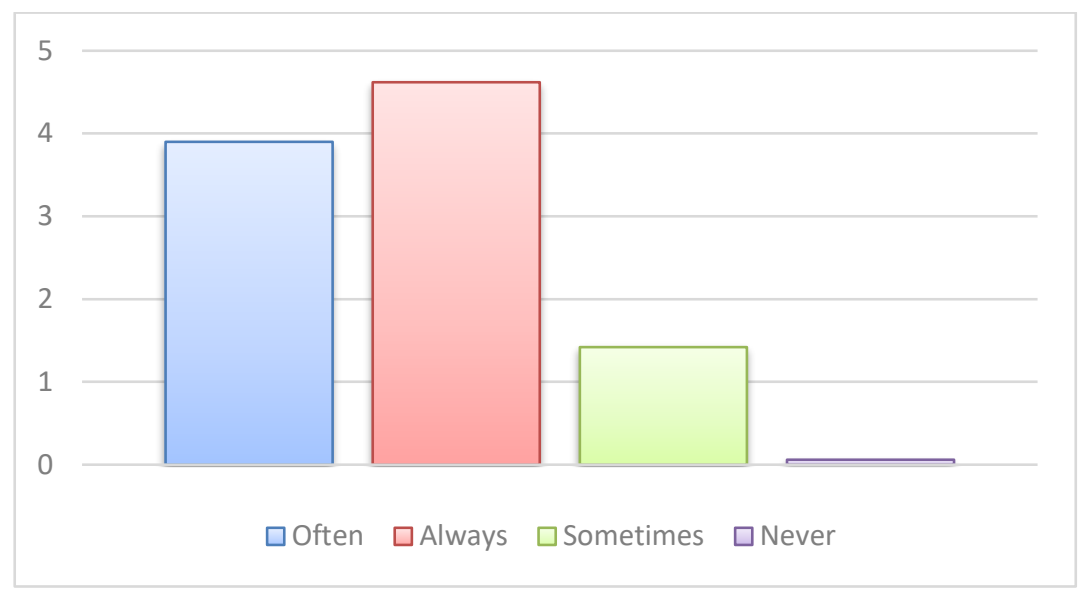

Figure 1.5 Science Teachers Apply a Scientific Approach to Science Learning

Based on the figure above, then in general IPA teachers then apply a scientific approach in science learning. This is seen in the figure above that the frequency of science teachers declaring often $3.9(39 \%)$, always $4.62(46.2 \%)$, sometimes $1.42(14.2 \%)$, and never 0.06 $(0.6 \%)$ not apply the scientific approach in science learning activities.

\section{Student Science Learning Activities at Madrasah Ibtidaiyah in Watampone}

Some of the learning activities of students at Madrasah Ibtidaiyah in Watampone are:

\section{Visual Activities}

Student learning activities at Madrasah Ibtidaiyah in Watampone start with visual activities. This form of activity is reading lesson materials, presenting pictures, demonstrating, conducting experiments and examining the work of students. The percentage of visual activity can be seen from the following poll results:

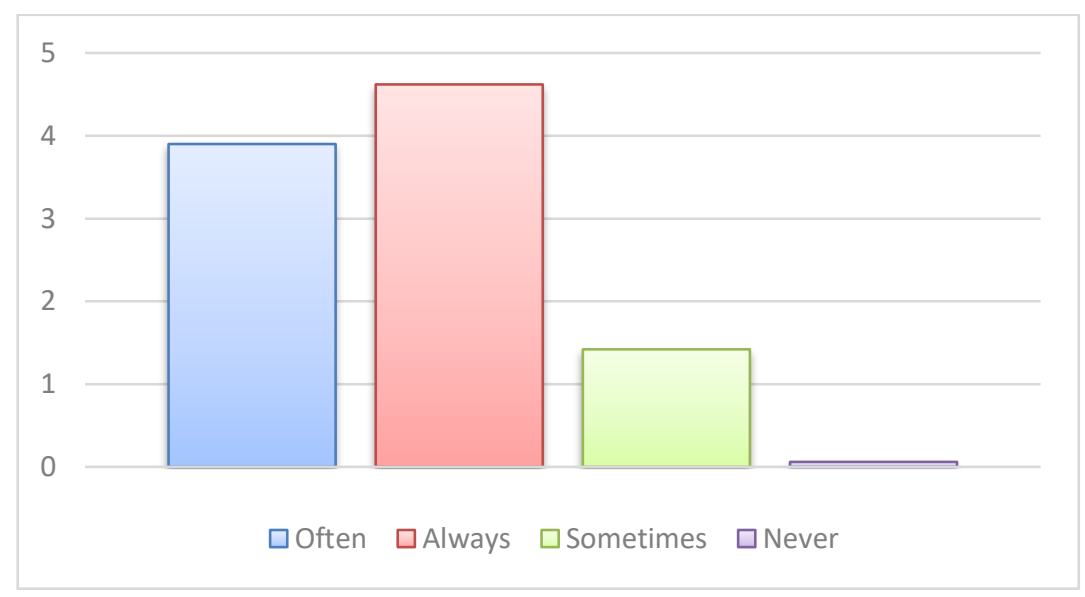

Figure 1.6 Visual Activities of Learners in Science Learning 
Based on the figure above, in general, students often do visual activities in science learning. This can be seen in the figure above that the frequency of students stated that they are often $5.25(52.5 \%)$, always $4(40 \%)$, sometimes $0.75(7.5 \%)$, and never $0.06(0.6 \%)$ do not do visual activities in science learning.

\section{Oral Activities}

Science lessons discuss among students and ask for an explanation from the teacher during the sharing process.

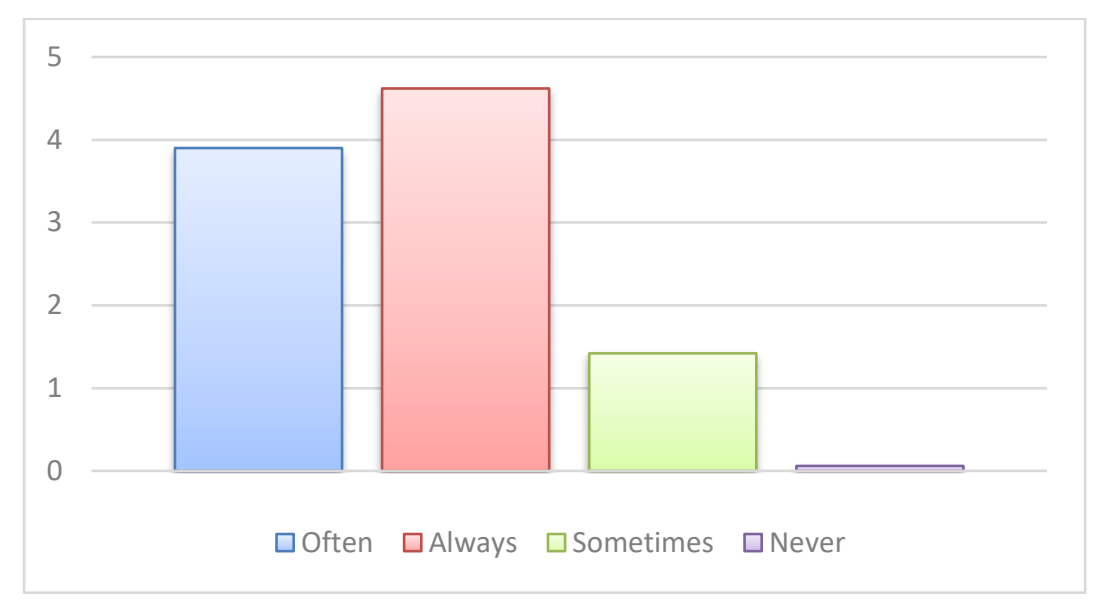

Figure 1.7 Oral Activities of Learners in Science Learning

Based on the figure above, in general, students often do oral activities in science learning. This can be seen in the figure above that the frequency of students stated that it is often 4.33 (43.3\%), always $4(40 \%)$, sometimes $1.67(16.7 \%)$, and never $0(0 \%)$. ) do not perform oral activities in science learning. The oral activities described above adjust the characteristics of the material, students, and learning objectives.

\section{Writing Activities}

The form of this activity is writing subject matter, resumes, or summarizing subject matter and taking tests or exercises. The results of the questionnaire can be seen in the following table: 


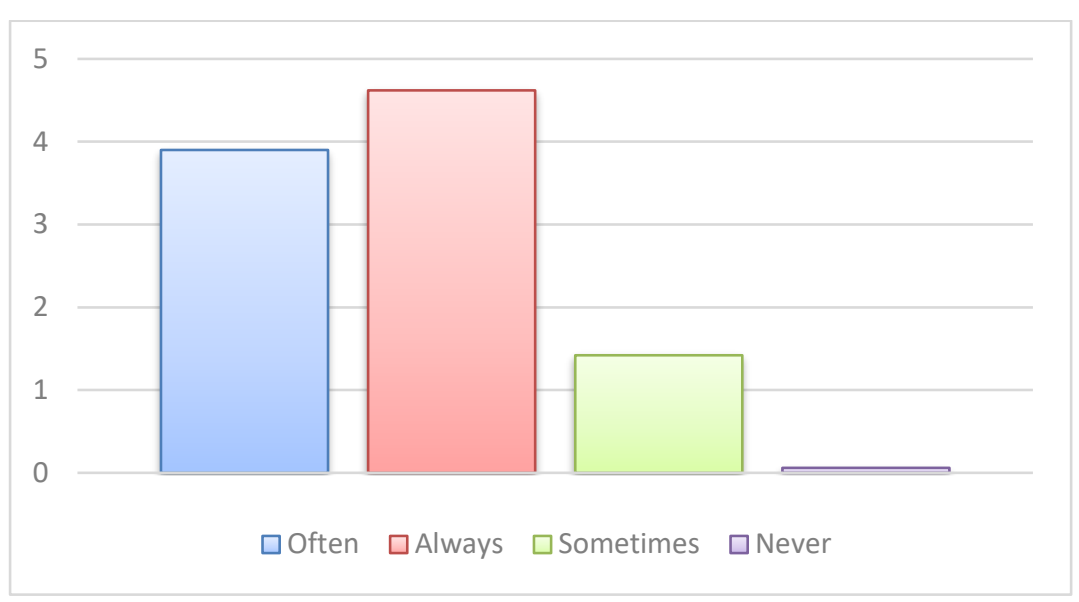

Figure 1.8 Student Writing Activities in Science Learning

Based on the figure above, in general, students often do writing activities in science learning. This can be seen in the figure above that the frequency of students stated that it is often $6.67(66.7 \%)$, always $3.33(33.3 \%)$, sometimes $0(0 \%)$, and never $0(0 \%)$. ) do not do writing activities in science learning.

\section{Listening Activities}

The form of this activity is listening to descriptions or explanations from the science teacher about the material being taught and using audio media so that students listen to the material through these media. The listening activities can be seen in the following table:

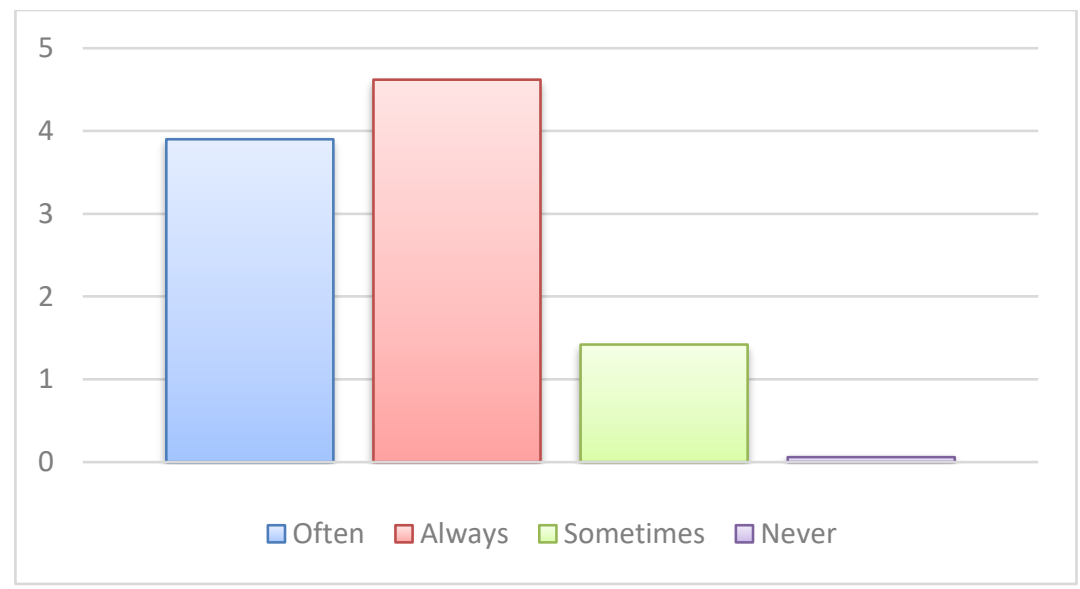

Figure 1.9 Student Listening Activity in Science Learning

Based on the figure above, in general students often do listening activities in science learning. This can be seen in the figure above that the frequency of students stated that they are often 4.5 (45\%), always $3.5(35 \%)$, sometimes 1 (10\%), and never $1(10 \%)$ do not do activities. listening in science learning.

\section{Drawing Activities}

Other learning activities carried out by students at Madrasah Ibtidaiyah at Watampone are drawing activities. The form of this activity is designing or drawing according to the subject 
matter, making graphs, maps, and diagrams in accordance with the material being taught. The results of the questionnaire from this drawing activity can be seen in the following table:

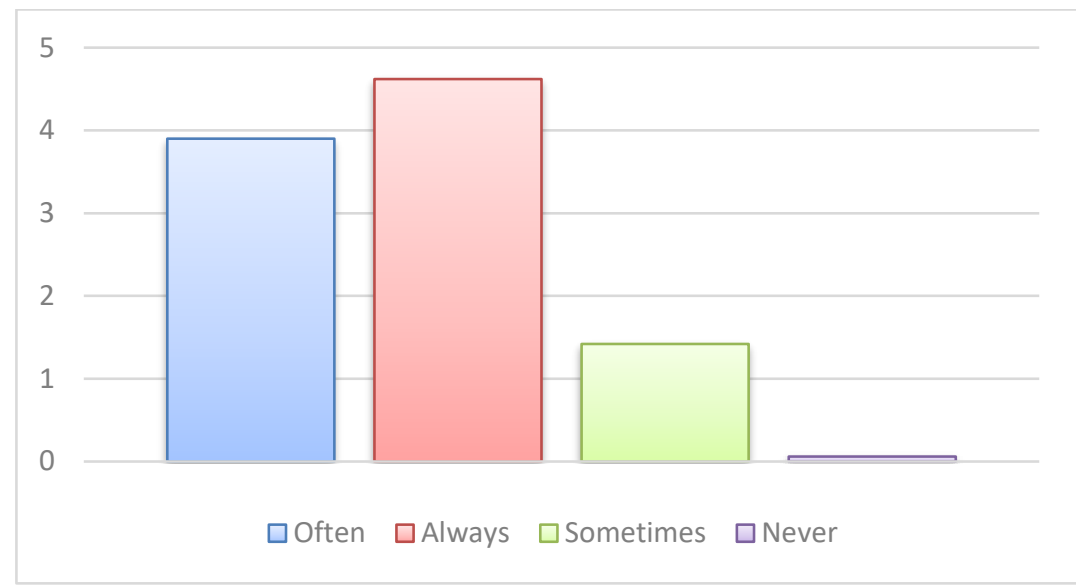

Figure 1.10 Drawing Activities of Learners in Science Learning

Based on the figure above, in general, students always do drawing activities in science learning. This can be seen in the figure above that the frequency of students stated that they are often $1.5(15 \%)$, always $5.5(55 \%)$, sometimes $3(30 \%)$, and never $0(0 \%)$ do not do activities. drawing in science learning.

\section{Motor Activities}

The form of this activity is conducting experiments, holding games, games and other activities according to the subject matter. The motor activities can be seen in the following table:

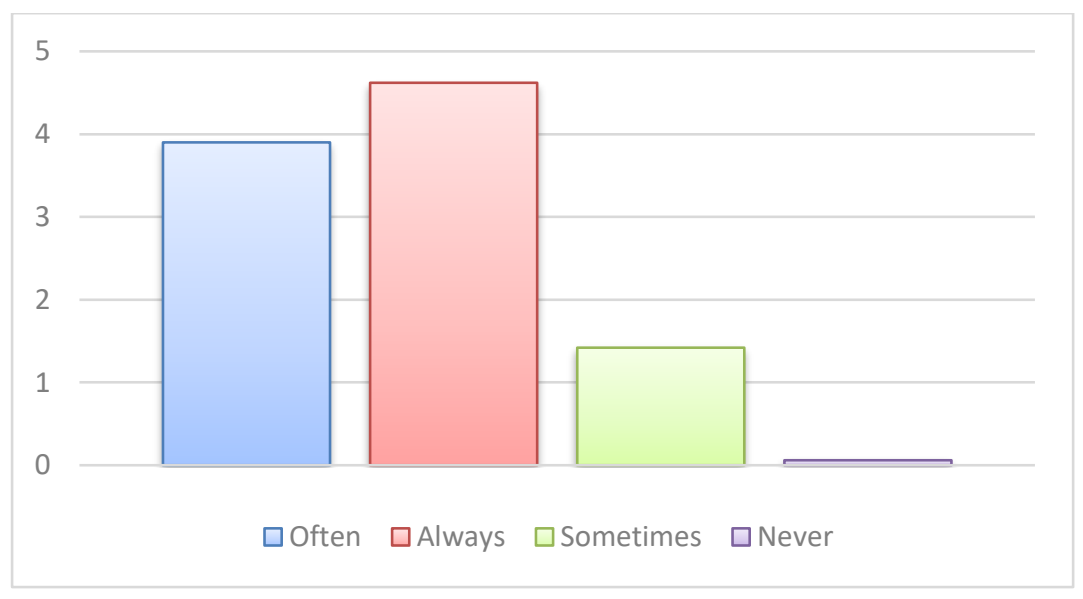

Figure 1.11 Student Mobile Activities in Science Learning

Based on the figure above, in general, students always carry out mobile activities in learning science. This can be seen in the figure above that the frequency of students stated that often 3 (30\%), always $4.5(45 \%)$, sometimes $2.5(25 \%)$, and never $0(0 \%)$ do not do activities engaged in science learning. 


\section{Mental Activities}

Other learning activities carried out by students at Madrasah Ibtidaiyah at Watampone are mental activities. The form of this activity is responding, recalling the material that has been taught, solving problems, analyzing, correlating and making decisions about the material being taught. The results of the questionnaire from this activity can be seen in the following table:

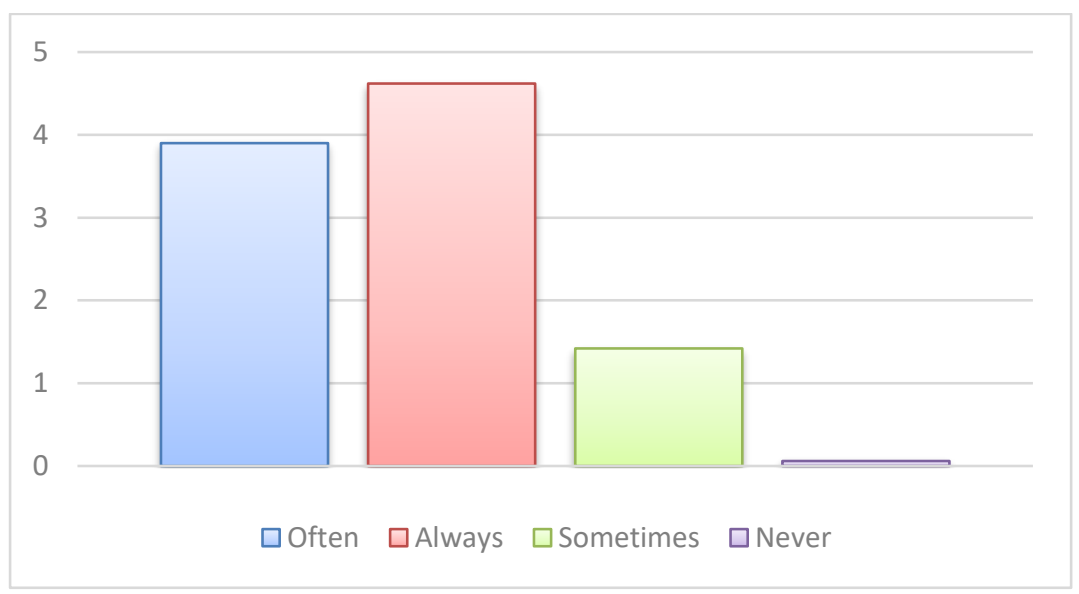

Figure 1.12 Mental Activities of Students in Science Learning

Based on the figure above, in general, students carry out mental activities in a balanced manner in science learning. This can be seen in the figure above that the frequency of students stated that they are often 4.67 (46.7\%), always $4.67(46.7 \%) \%)$, sometimes 0.66 $(6.6 \%)$, and never $0(0 \%)$ did not do mental activity in science learning.

\section{Emotional Activities}

The form of this activity is paying attention to the lessons given, feeling happy with the way the teacher teaches and the assignments given, daring to express opinions, calm, enthusiastic in participating in lessons, and having opinions and asking questions during the learning process. The results of the questionnaire from this activity can be seen in the following table:

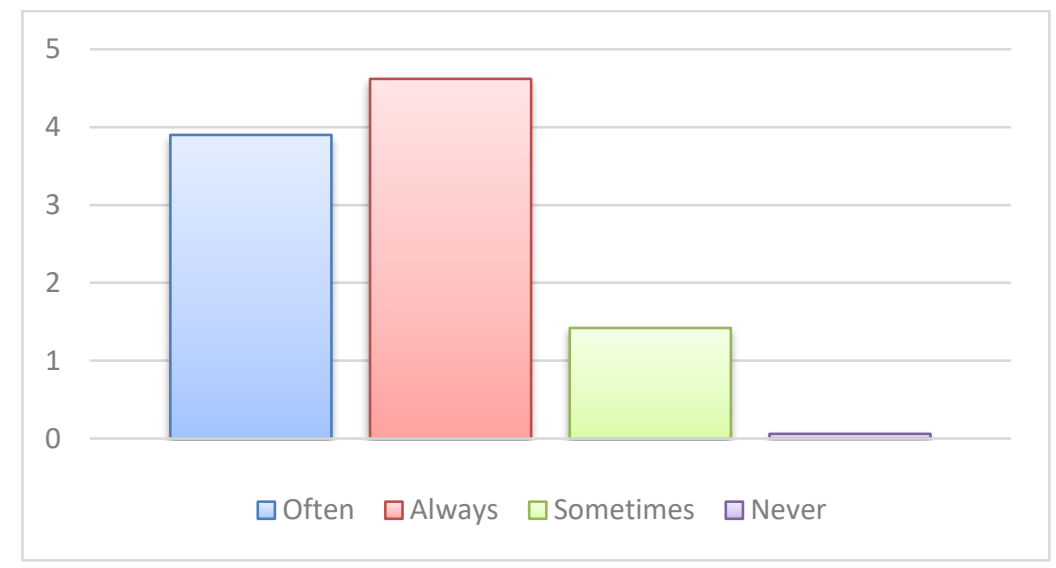

Figure 1.3 Emotional Activities of Learners in Science Learning 
Based on the figure above, in general, students often do emotional activities in science learning. This can be seen in the figure above that the frequency of students stated that it is often 4.9 (49\%), always $3.6(36 \%)$, sometimes $1.4(14 \%)$, and never $0.2(2 \%)$. ) never do emotional activities in science learning. Cumulatively, the learning activities of students in learning can be seen in the figure below:

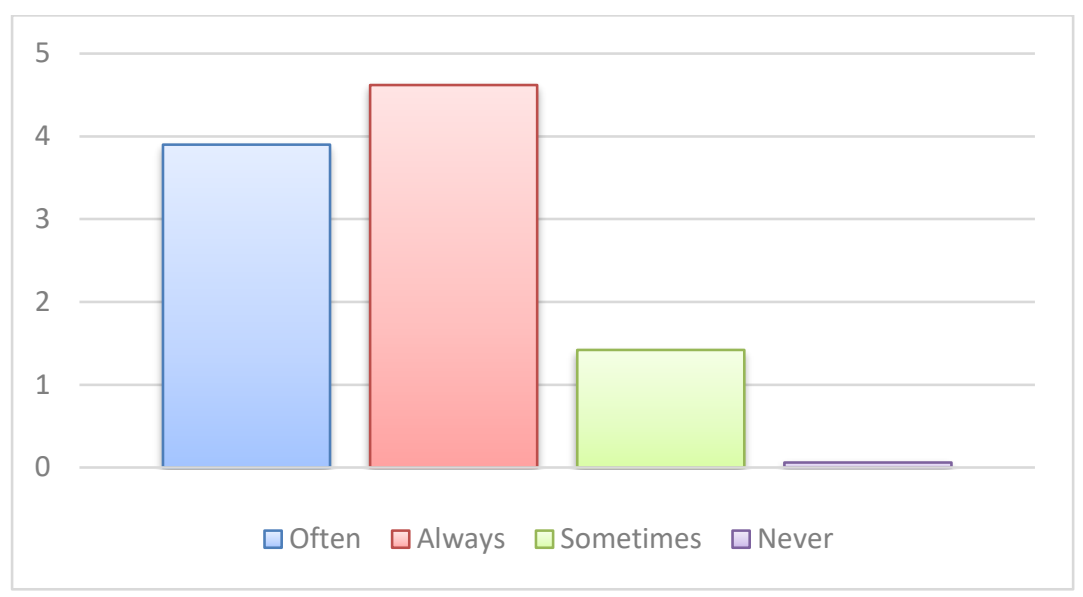

Figure 1.14 Student Learning Activities in Science Learning

Based on the figure above, in general, students often do learning activities in science learning. This can be seen in the figure above that the frequency of students stated that it is often 4.34 (43.4\%), always 4.14 (41.4\%), sometimes 1.37 (13.7\%), and never $0.15(1.5 \%)$ do not do learning activities in science learning. Thus, all student activities have been carried out properly by students and the science teacher has also provided guidance, encouragement or motivation in increasing all the activities above, whether visual, oral, listening, writing, drawing, motorbike, mental, and emotional activities.

\section{The Influence of Scientific Approach on Science Learning on Improving Student Learning Activities at Madrasah Ibtidaiyah in Watampone}

The scientific approach to science learning towards increasing student learning activities at Madrasah Ibtidaiyah in Watampone has a moderate positive effect. Based on this, the researcher explains and provides analysis in accordance with the results of the study. The discussion analysis can be described as follows:

Tabel 1.7 Descriptive Statistics

\begin{tabular}{|l|r|r|r|}
\hline \multicolumn{1}{|c|}{ Research Variables } & \multicolumn{2}{|c|}{ Mean } & Std. Deviation \\
\hline Learning Activities & 79.40 & 4.881 & 10 \\
\hline Scientific Approach & 55.50 & 5.169 & 10 \\
\hline
\end{tabular}

In the summary table model, it can be analyzed that there is a significant relationship or correlation between the scientific approach and the learning activities of students, namely a high positive correlation with a value of $r=0.436$. This means that it is high or strong positive because the relationship between variables $\mathrm{X}$ and $\mathrm{Y}$ is unidirectional. The purpose is 
unidirectional here that the longer the scientific approach is applied to the science teacher, the learning activities of students will increase. Vice versa. Furthermore, the contribution that the scientific approach (X) contributed to the learning activities of students at Madrasah Ibtidaiyah in Watampone $(\mathrm{Y})=1,877 \%$. The model summary table can be seen below:

Tabel : 8 Model Summary

\begin{tabular}{|c|c|c|c|c|c|c|c|c|c|}
\hline \multirow{2}{*}{$\begin{array}{c}\text { Mode } \\
1\end{array}$} & \multirow[t]{2}{*}{$\mathrm{R}$} & \multirow{2}{*}{$\begin{array}{c}\mathrm{R} \\
\text { Squar } \\
\mathrm{e}\end{array}$} & \multirow{2}{*}{$\begin{array}{l}\text { Adjus } \\
\text { ted R } \\
\text { Squar } \\
\text { e }\end{array}$} & \multirow{2}{*}{$\begin{array}{l}\text { Std. } \\
\text { Error of } \\
\text { the } \\
\text { Estimat } \\
\mathrm{e} \\
\end{array}$} & \multicolumn{5}{|c|}{ Change Statistics } \\
\hline & & & & & $\begin{array}{c}\text { R Square } \\
\text { Change }\end{array}$ & $\begin{array}{c}\text { F } \\
\text { Chan } \\
\text { ge }\end{array}$ & $\begin{array}{c}\mathrm{df} \\
1\end{array}$ & $\begin{array}{l}\mathrm{d} \\
\mathrm{f} \\
2\end{array}$ & $\begin{array}{c}\text { Sig. F } \\
\text { Change }\end{array}$ \\
\hline 1 & $\begin{array}{c}.436 \\
\mathrm{a}\end{array}$ & .190 & .089 & 4.659 & .190 & 1.877 & 1 & 8 & .208 \\
\hline
\end{tabular}

In the ANOVA table, it can be analyzed:

Ho : Simple linear regression models cannot be used in predicting learners' learning activities influenced by scientific approaches

$\mathrm{Ha}$ : A simple linear regression model can be used in predicting learners' learning activities influenced by scientific approaches

If: $\leq$, then Ho is accepted $F_{\text {hitung }} F_{\text {tabel }}$

If: >, then Ho is rejected $F_{\text {hitung }} F_{\text {tabel }}$

Where:

The value of the ANOVA table is 1,877 and the value from table $\mathrm{F}=0.4 . F_{\text {hitung }} F_{\text {tabel }}$

Based on probability value:

If probability ( $\mathrm{sig})>\alpha$ then Ho is accepted

If probability (sig) $<\alpha$ then Ho is rejected

Where:

From the ANOVA table the probability value (sig) $=0.208$ and the significant grade value $\alpha$ $=0.05$. Furthermore, when compared with sig and $\alpha$, it turns out: $=1,877>=0.4$ then Ho rejected $F_{\text {tabel }} F_{\text {hitung }} F_{\text {hitung }} F_{\text {tabel }}$

And it turns out: $0.208>0.05$ then Ho accepted. So, a simple linear regression model can be used to predict the level of learning activity of learners influenced by scientific approaches. ANOVA table can be seen below:

Table:9 Anova Analysis Results

\begin{tabular}{|c|c|c|c|c|c|}
\hline Model & Sum of Squares & Df & Mean Square & $\mathrm{F}$ & Sig \\
\hline Regression & 40.753 & 1 & 40.753 & 1.877 & $.208^{\mathrm{b}}$ \\
\hline Residual & 173.647 & 8 & 21.706 & & \\
\hline Total & 214.400 & 9 & & & \\
\hline \multicolumn{6}{|c|}{ a. Dependent Variable: Learning Activities } \\
\hline b. Predi & cientifi & oach & & & \\
\hline
\end{tabular}


When viewed from the coefficients table, it can be analyzed that the regression equation model to estimate the increase in student learning activities influenced by the scientific approach is $\mathrm{Y}=56.554+0.412 \mathrm{X}$. Where $\mathrm{Y}$ is the learning activity of students and $\mathrm{X}$ is the scientific approach. The above equation can be analyzed several things, including: That if the teacher does not have a scientific approach $(X=0)$ it is estimated that he will be able to increase the learning activities of students 56,554 =56, whereas if he has used the scientific approach for 2 years $(X=2)$, it is estimated that he will be able to increase the learning activities of the participants. students as much as $56,554+0,412(2)=57$. The regression coefficient $b=0.412$ indicates an increase in the level of student learning activity for each scientific approach, although the addition is small.

Table:10 Coefficients

\begin{tabular}{|c|c|c|c|c|c|c|c|}
\hline \multirow[t]{2}{*}{ Model } & \multicolumn{2}{|c|}{$\begin{array}{l}\text { Unstandardized } \\
\text { Coefficients }\end{array}$} & \multirow{2}{*}{$\begin{array}{c}\text { Standardized } \\
\text { Coefficients } \\
\text { Beta }\end{array}$} & \multirow[t]{2}{*}{$\mathrm{T}$} & \multirow[t]{2}{*}{ Sig. } & \multicolumn{2}{|c|}{$\begin{array}{l}95.0 \% \text { Confidence } \\
\text { Interval for B }\end{array}$} \\
\hline & B & $\begin{array}{l}\text { Std. } \\
\text { Error }\end{array}$ & & & & $\begin{array}{l}\text { Lower } \\
\text { Bound }\end{array}$ & $\begin{array}{l}\text { Upper } \\
\text { Bound }\end{array}$ \\
\hline (Constant) & $\begin{array}{r}56.55 \\
4\end{array}$ & 16.738 & & $\begin{array}{r}3.37 \\
9\end{array}$ & .010 & 17.955 & 95.153 \\
\hline $\begin{array}{l}\text { Scientific } \\
\text { Approach }\end{array}$ & .412 & .300 & .436 & $\begin{array}{r}1.37 \\
0\end{array}$ & .208 & -.281 & 1.104 \\
\hline
\end{tabular}

Next. progression regression $\mathrm{Y}=56.554+0.412 \mathrm{X}$ used as the basis for estimating the activity level of learners affected by the scientific approach will be tested for validity. To test the validity of regression equations, it can be used in two ways, namely based on t-test and based on probability technique. Based on the t-test, the steps are:

1. Hypothesize in sentence form

Ho : There is no influence between scientific approach and student learning activities

$\mathrm{Ha}$ : There is an influence between scientific approach and learning activities

2. Create hypotheses in the form of statistical models

Ho : $\mathrm{a}=0$

Ha $: \mathrm{a} \neq 0$

3. Test rules

If, accepted $-t_{\text {table }} \leq t_{\text {count }} \leq t_{\text {table }}$, So $H_{o}$

If, rejected $t_{\text {count }}>t_{\text {table }}$, So $H_{o}$

Based on table coefficients $(a)$ obtained value $=1,370 t_{\text {count }}$

Values can be searched by using the $\mathrm{t}-t_{\text {table }}$ student table

$$
\begin{aligned}
t_{\text {table }} & =t_{\left(\frac{\alpha}{2}\right)(n-2)} \\
& =t_{\left(\frac{0,05}{2}\right)(10-2)} \\
& =t_{(0,025)(8)} \\
& =0,2
\end{aligned}
$$

1. Compare $t_{\text {tabel }}$ dan $t_{\text {hitung }}$ 


$$
\text { Apparently }=1,370>=0.2 \text { then Ho rejected } t_{\text {hitung }} t_{\text {tabel }}
$$

2. Make a decision

There is a significant influence between scientific approaches and increased learning activities of learners.

Based on probability techniques, the steps are:

1. Hypothesize in sentence form

Ho: There is no influence between scientific approach and student learning activities

Ha: There is an influence between scientific approach and learning activities

2. Create hypotheses in the form of statistical models

Ho: $\mathrm{a}=0$

Ha: $\mathrm{a} \neq 0$

3. Define test criteria

If: $\mathrm{Sig} \leq \alpha$, then Ho is rejected

If: $\mathrm{Sig}>\alpha$, then Ho is accepted

Based on the table coefficients ( $a$ ) diproleh sig value $=0,2$

The $\alpha$ value, because the test is two-sided then the $\alpha$ value is divided by 2 so that the $\alpha$ $=0.05 / 2=0.025$

4. Compare

Turns out: $\operatorname{Sig}=0.2>0.025$, then Ho accepted

5. Make a decision

There is no significant influence between scientific approaches and increased learning activities.

\section{Correlations}

Table: 11 Correlations

\begin{tabular}{|c|c|c|c|}
\hline & & $\begin{array}{c}\text { Social Media } \\
\text { Language }\end{array}$ & $\begin{array}{l}\text { Social Media } \\
\text { Learning }\end{array}$ \\
\hline \multirow[t]{3}{*}{ Social Media Language } & Pearson Correlation & 1 & $.518^{* *}$ \\
\hline & Sig. (2-tailed) & & .000 \\
\hline & $\mathrm{N}$ & 82 & 82 \\
\hline \multirow[t]{3}{*}{ Social Media Learning } & Pearson Correlation & $.518^{* * *}$ & 1 \\
\hline & Sig. (2-tailed) & .000 & \\
\hline & $\mathrm{N}$ & 82 & 82 \\
\hline
\end{tabular}

Table 4-26 states the relationship between social media language and social media learning. The positive values ( 1 and .518) of correlation between social media language and social media learning were observed with $.000 \mathrm{sig}$. value. In the table, the same values have been observed diagonally for both variables. The positive values of correlation for both the variables indicate that both the variables are perfectly positively interlinked. Since, ' $p$ ' value $(\mathrm{p}=.000)$ is less than alpha (.05). Therefore, the correlation is statistically significant (Chandra Kafle, 2019). Hence, the correlation between the variables rejects the null hypotheses of the research. 


\section{Linear Regression Analysis}

Linear regression is used to predict the values of variables in which the value of one variable (dependent variable/ outcome variable) depends on the value of another variable (independent variable/ predictor variable) (Chandra Kafle, 2019).

Table 4-1ANOVA ${ }^{\mathrm{a}}$

\begin{tabular}{|l|l|c|c|c|c|c|}
\hline Model & Sum of Squares & Df & Mean Square & F & Sig. \\
\hline \multirow{3}{*}{1} & Regression & 11.556 & 1 & 11.556 & 29.267 & $.000^{\mathrm{b}}$ \\
\cline { 2 - 7 } & Residual & 31.587 & 80 & .395 & & \\
\cline { 2 - 7 } & Total & 43.143 & 81 & & & \\
\hline
\end{tabular}

ANOVA lets us know how significant our model is. The sig. value $(\mathrm{p}=.000)$ in Table $4-27$ is less than alpha (.05) which indicates that the model is highly significant statistically. The model significance can be reported as F $(1,80)=29.267, \mathrm{p}=.000$ (Samuels \& Gilchrist, $2014 b$ ). Thus, it can easily be interpreted that the outcome variable (social media learning) has significantly been impacted by the predictor (social media language).

Table 4-2Coefficients ${ }^{\mathrm{a}}$

\begin{tabular}{|c|c|c|c|c|c|c|}
\hline \multicolumn{2}{|c|}{ Model } & \multicolumn{2}{|c|}{ Unstandardized Coefficients } & \multirow{2}{*}{$\begin{array}{c}\begin{array}{c}\text { Standardized } \\
\text { Coefficients }\end{array} \\
\text { Beta }\end{array}$} & \multirow[t]{2}{*}{$\mathbf{T}$} & \multirow[t]{2}{*}{ Sig. } \\
\hline & & $\mathbf{B}$ & Std. Error & & & \\
\hline \multirow[t]{2}{*}{1} & (Constant) & 1.483 & .206 & & 7.214 & .000 \\
\hline & Social Media Language & .649 & .120 & .518 & 5.410 & .000 \\
\hline
\end{tabular}

The Table 4-28 regards both the variables distinctively using a linear regression equation that whether the variables are significant or not. In this table, the sig. value of predictor 'constant' is not important to consider. However, the sig. value for both the variables $(p=.000)$ is less than alpha (.05), and therefore, the results for the coefficients of variables show a high significance statistically (Kpolovie, 2017). So, it can be construed that the English language used in social media highly impacts the language learning of the English language learners. Hence, the analysis rejects the null hypotheses of the study and accepts alternate hypotheses.

\section{Findings}

The results on subsequent completion of the descriptive analysis revealed that social media played a dominant role in improving the English language of the learners. Social media assisted the learners to learn new English words and phrases enhancing their vocabulary. The results of the study indicated that listening and watching audiovisual content on social media in the English language proved instrumental in enhancing the listening and speaking skills of the learners. It has also been unfolded that the online written conversations on social media psychologically urge the learners to write English in a better way using correct grammar and appropriate vocabulary which help in improving the writing skills of the learners. Expeditiously written conversations on social media also help in improving the readability and comprehension skills of the learners as well. The results conspicuously indicated that 
social media advances the English learnability of the English language learners and is instrumental in enhancing vocabulary and improving the overall reading, writing, listening and speaking skills of the learners. However, it was also found that the excessive use of shortened forms of words and phrases, slang and short sentences with incorrect grammar on social media adversely affect the academic writings of the learners. On the whole, it was revealed that the majority of the learners tend to favour learning English through social media which showed a positive impact of social media language on the English language learners.

Similarly, the results of inferential analysis indicated that the dependent variable (social media learning) has significantly been impacted by the independent variable (social media language). It corroborates that the analysis rejects the null hypotheses and accepts alternate hypotheses. Finally, the findings of both descriptive and inferential analyses substantiated that the English language used in social media positively impacted the perception and language learnability of the English language learners. Hence, it can easily be construed from the whole analysis that the social media strengths were by far greater than the social media weaknesses.

\section{Conclusion and Suggestion}

In general, science teachers have applied a scientific approach to their learning. The application of the scientific approach has gone through and is in accordance with the existing procedures in the scientific approach starting from observation, asking questions, experimenting, associating, and forming networks. Science teachers have also increased the learning activities of students in their learning. Increased learning activities begin with visual, oral, listening, writing, drawing, physical or movement, mental and emotional activities. The scientific approach to science learning towards increasing student learning activities at Madrasah Ibtidaiyah in Watampone has a moderate positive effect with a value of $r=0.436$. This influence is positive, meaning that it is a unidirectional influence between the $\mathrm{X}$ and $\mathrm{Y}$ variables, if this approach continues to be used by science teachers in learning, the learning activities of students will increase.

Learning with a scientific approach is an approach to developing the creativity of students through scientific procedures of students as has been applied to Madrasah Ibtidaiyah in Watampone. The current 2013 curriculum is very suitable and very suitable for the application of a scientific approach based and centered on student learning activities. Thus, it requires the will, awareness and skills of the school community in providing thematic learning with a scientific approach to hone and develop various abilities and creativity of students in learning so that the desired learning objectives and learning quality are achieved.

And it can also be developed in various aspects such as sociological, anthropological and so on; For education stakeholders both in the Education Office or the Ministry of Religion, to conduct various training or seminars related to the optimization of the scientific approach in thematic learning so that teachers can understand the concept of thematic learning through a scientific approach; Systemic and systematic steps are needed to further develop the scientific approach of the competent and competent authorities at the Madrasah Ibtidaiyah level at Watampone, and the provision of more adequate facilities or learning resources so that the 
application of this scientific approach is more optimally implemented by teachers in Madrasahs and not only at the primary school / Madrasah Ibtidaiyah stage but starting from the Early Childhood Islamic Education stage; It takes the involvement of parents in developing their children's scientific thinking. So, the development and application of science are not only focused on schools but the development of scientific thinking can be done by parents in the family and society.

\section{Acknowledgments}

The author would like to thank all those who have contributed to this research so that finally this article was produced, especially to the respondents, namely the principal, classroom teachers, and students at Madrasah Ibtidaiyah in Watampone, and to the Bone State Islamic Institute for providing material and assistance.

\section{Conflict of Interest}

The authors declare no conflict of interest

\section{Funding}

The study was not funded by any institution/ university.

\section{Availability of Data and Material}

The data that support the findings of this study are available from the corresponding author, upon reasonable request.

\section{References}

Abdurrahmansyah. (2014). Model Pembelajaran Untuk Meningkatkan Kemampuan Pedagogical Content Knowledge Pada Mahasiswa Tarbiyah di Lembaga Pendidikan Tinggi Agama Islam. Universitas Pendidikan Indonesia.

Arikunto, S. (2006). Prosedur Penelitian: Suatu Pendekatan Praktek. Rineka Cipta.

Darmadi, H. (2014). Metode Penelitian Pendidikan dan Sosial: Teori, Konsep Dasar dan Implementasi. Alfabeta.

Darwis, A. (2014). Metode Penelitian Pendidikan Islam: Pengembangan Ilmu Berparadigma Islami. Rajawali Pers.

Daryanto., Karim, S. (2017). Pembelajaran Abad 21. Ghava Media.

Daryanto. (2014). Pendekatan Pembelajaran Saintifik Kurikulum 2013 (Cet. I). Gava Media.

Daryanto. (2017). Pembelajaran Abad 21. Gava Media.

Diedrich, P. B. as cited in, \& Hanafiah, Nanang dan Suhana, C. (2010). Konsep Strategi Pembelajaran. Refika Aditama.

Ghozali, I. (2011). Aplikasi Analisis Multivariate dengan Program IBM SPSS 19. Universitas Diponegoro.

Hajar, I. (1996). Dasar-dasar Metodologi Penelitian Kuantitatif dalam Pendidikan. Raja 
Grafindo Persada.

Herdiansyah, H. (2010). Metodologi Penelitian Kualitatif. Jakarta: Salemba Humanika.

Hosnan, M. (2014). Pendekatan Saintifik dan Kontekstual dalam Pembelajaran Abad 21. Ghalia Indonesia.

Kadir, A., \& Asrohah, H. (2014). Pembelajaran Tematik. Rajawali Pers.

Kosasih, E. (2016). Strategi Belajar dan Pembelajaran: Implementasi Kurikulum 2013. Yrama Widya.

Mudlofir, A., \& Rusydiyah, E. F. (2016). Desain Pembelajaran Inovatif: Dari Teori ke Praktik. Rajawali Pers.

Nurdin, S., \& Adriantoni. (2016). Kurikulum dan Pembelajaran. Rajawali Pers.

Republik Indonesia. (2006). Undang-Undang Republik Indonesia No. 20 Tahun 2003 tentang Sistem Pendidikan Nasional. Fokus Media.

Ridwan. (2012). Metode dan Teknik Menyusun Proposal Penelitian. Alfabeta.

Rusman. (2012). Model-Model Pembelajaran Mengembangkan Profesionalisme Guru. Raja Grafindo Persada.

Rusman. (2015). Pembelajaran Tematik Terpadu : Teori, Praktik dan Penilaian (I). Rajawali Pers.

Samatowa, U. (2016). Pembelajaran IPA di Sekolah Dasar. Indeks.

Sani, R. A. (2015). Pembelajaran Saintifik Untuk Implementasi Kurikulum 2013. Bumi Aksara.

Sardiman. (2001). Interaksi dan Motivasi Belajar Mengajar. Raja Grafindo Persada.

Siregar, S. (2015). Statistik Parametrik Untuk Penelitian Kuantitatif. Bumi Aksara.

Singer, L. M., \& Alexander, P. A. (2017). Reading on paper and digitally: What the past decades of empirical research reveal. Review of educational research, 87(6), 1007-1041.

Sudjono, A. (2005). Pengantar Statistik Pendidikan. Raja Grafindo Persada.

Sugiyono. (2011). Metode Penelitian Kombinasi (Mixed Methods) (Sutopo (ed.); 1st ed.). Alfabeta.

Sundayana, W. (2014). Pembelajaran Berbasis Tema: Panduan Guru Mengembangkan Pembelajaran Terpadu. Erlangga.

Tobin, K. (2006). Handbook of Teaching and Learning Science. Prager Publisher.

Yaumi, M. (2013). Prinsip-Prinsip Desain Pembelajaran. Prenada Media Group.

McKernan, J. (2007). Curriculum and imagination: Process theory, pedagogy and action research. Routledge.

Demina, D., Effendi, Z. M., Ananda, A., \& Damansyah, D. (2019). Application of Integrated Learning Model on Islamic Education in Improving Students Self Control in Madrasah Ibtidaiyah. In 1st International Conference on Innovation in Education (ICoIE 2018) (pp. 65-70). Atlantis Press.

Wangid, M. N. (2014). Student-centered learning: Self-regulated learning. In International Conference on Fundamentals and Implementation of Education (ICFIE) (pp. 161-165). 